\title{
MENGGAGAS DESA WISATA PLUNTURAN BERBASIS KEARIFAN LOKAL DI KABUPATEN PONOROGO JAWA TIMUR
}

\author{
Anggraeny Puspaningtyas ${ }^{1}$, Tri Pramesti ${ }^{2}$, Ingesti Lady Rara P. ${ }^{3}$, Mita Octaviani ${ }^{4}$ \\ Universitas 17 Agustus 1945 Surabaya ${ }^{1,2,3,4}$ \\ anggraenypuspa@untag-sby.ac.id ${ }^{1}$,pramestimursidi@gmail.com ${ }^{2}$, \\ ingestirara07@gmail.com ${ }^{3}$, mitaoctaviani1010@gmail.com ${ }^{4}$
}

\begin{abstract}
Plunturan is one of villages in Ponorogo, East Java Province. The prime product of Plunturan Village is a cultural heritage that is still maintained by the local village community. The various cultural products are Reyog (Reyog Anak, Reyog Perempuan dan Reyog Taruna); Gajah-Gajahan; Jathilan; Ganongan; Tledekan; Karawitan; Wayang Kulit; Coke'an; Metik Desa; Metri Desa; Metri Tandur; Campursari; and Sego Angkruk. Artists come from across generations, passed down through village elders and art groups. Artists today do not consider the potential of art in their village as their main source of income. They have other livelihoods such as farmers, traders, civil servants, government officials, teachers, health workers, private employees. This condition causes a lack of initiative from artists to attract tourists from outside the region. The role of stakeholders in Plunturan Village is very important in developing cultural tourism. The Tourism Awareness Group (Pokdarwis) which is the driving force for cultural tourism development activities must develop a strategy to make Plunturan a tourism village. Therefore, this service uses a SWOT analysis (strengths, weaknesses, opportunities and treath) to find out what strategies should be taken to initiate Plunturan Tourism Village based on local wisdom. So that culture-based development is not only aimed at improving culture, but also in carrying out development it is necessary to base on the culture that is owned, especially regarding value systems, attitudes and customs.
\end{abstract}

Keywords: cultural heritage, tourism development, development srategy

\section{PENDAHULUAN}

Pariwisata di Indonesia mengalami gebrakan baru di tahun 2014 yaitu ditetapkan sebagai sektor prioritas pembangunan yang diharapkan dapat memberikan kontribusi besar terhadap pemasukan devisa negara. Pada saat yang sama, tren global menunjukkan bahwa sektor pariwisata merupakan sektor ekonomi yang sangat prospektif. UN World Tourism Organization (UNWTO) memperkirakan sekitar $40 \%$ dari wisatawan global melakukan perjalanan wisata dengan maksud lebih mengenal keberagaman budaya. "Pariwisata berbasis budaya lebih memfokuskan pada pengalaman baru dari tempat dan kegiatan yang merepresentasikan cerita-cerita masa lalu dan kekinian" (Hartono dan Sumaryadi, 2018:2). Berbagai festival, ritual, museum, teater situs bersejarah, dan fasilitas budaya merupakan elemen wisata budaya (cultural heritage tourism) yang menjadi tujuan wisatawan pada saat ini. Menurut Hartono dan Sumaryadi, "Wisata budaya tidak sekedar berbicara bisnis pariwisata semata, tetapi juga melihat relasi pertukaran budaya (cultural exchange). Produk wisata budaya tidak diposisikan hanya sebagai komoditas untuk kepentingan profit bagi industri pariwisata saja, tetapi juga sebagai produk budaya yang dimiliki masyarakat setempat dan harus dihormati keberadaannya" (2018:ii). Pengembangan wisata budaya diatur dalam norma-norma yang diatur dalam UndangUndang Nomor 10 Tahun 2009 tentang Kepariwisataan:

a. Menjunjung tinggi norma agama dan nilai budaya sebagai pengejewantahan dari konsep hidup dalam keseimbangan hubunngan antara manusia dan Tuhan Yang Maha Esa, hubungan antara manusia dan sesama manusia, dan hubungan antara manusia dan lingkungan;

b. Menjunjung tinggi hak asasi manusia, keragaman budaya dan kearifan lokal;

c. Memberi manfaat untuk kesejahteraan rakyat, keadilan, kesetaraan, dan proporsionalitas; 
d. Memelihara kelestarian alam dan lingkungan hidup;

e. Memberdayakan masyarakat setempat;

f. Menjamin keterpaduan antarsektor, antardaerah, antara pusat dan daerah yang merupakan satu kesatuan sistemik dalam kerangka otonomi daerah, serta keterpaduan antarpemangku kepentingan;

g. Mematuhi kode etik kepariwisataan dunia dan juga kesepakatan internasional dalam bidang pariwisata;

h. Memperkukuh keutuhan Negara Kesatuan Republik Indonesia.

Landasan kebijkaan nasional yang menjadi pengembagan pariwisata budaya pemerintah daerah diantaranya adalah sebagai berikut:

1. Undang-Undang Dasar Republik Indonesia Tahun 1945

2. Kebijakan kepariwisataan yang terkait dengan pengembangan wisata tematik berbasis budaya, meliputi:

a. Undang-Undang Nomor 10 tahun 2009 tentang Kepariwisataan;

b. Peraturan Pemerintah Nomor 50 Tahun 2011 tentang Rencana Induk Pembangunan Pariwisata Nasional Tahun 2010-2025;

c. Peraturan Menteri Pariwisata Nomor 14 Tahun 201 tentang Pedoman Destinasi Pariwisata Berkelanjutan;

d. Peraturan Menteri Pariwisata Nomor 11 Tahun 2017 tentang Organisasi dan Tata Kerja Kerja Kementerian Pariwisata

3. Kebijakan tata ruang yang terkait dengan pengembangan wisata berbasis budaya, meliputi:

a. Undang-Undang 26 Tahun 2007 tentang Penataan Ruang;

b. Peraturan Pemerintah Nomor 26 Tahun 2008 tentang Rencana Tata Ruang Wilayah Nasional.

4. Kebijakan kebudayaan dan pelestarian yang terkait dengan pengembangan wisata berbasis budaya

a. Undang-Undang Nomor 5 Tahun 2017 tentang Pemajuan Kebudayaan;

b. Undang-Undang Nomor 11 Tahun 2010 tentang Cagar Budaya;

c. Peraturan Presiden Nomor 78 Tahun 2007 tentang Pengesahan Convention For

The Safeguarding of The Intangible Cultural Heritage (Konvensi untuk Perlindungan Warisan Budaya Takbenda)

Pengembangan wisata berbasis budaya yang telah dirancang di pemerintahan pusat, menjadi acuan dan arahan bagi Pemerintah Daerah dan para stakeholder kepariwisataan dalam pengembangan pariwisata budaya di tingkat provinsi, kabupaten/kota yang dapat dikembangkan dan dikemas sendiri menjadi produk wisata yang unik sesuai dengan karakter daerah masing- masing. Pengembangan wisata budaya diharapkan mampu mencapai tujuan dan manfaat yang signifikan bagi stakeholder yang terkait sektor wisata budaya. Pengabdi beranggapan ada lima stakeholder yang harus terlibat dalam pengembangan wisata budaya yaitu pemerintah, komunitas, industri/bisnis, akademisi dan media.

Berdasarkan hasil observasi dan survei pengabdi, Desa Plunturan merupakan salah satu desa yang terletak di Kabupaten Ponorogo memiliki banyak produk budaya dan masih dipertahankan. Salah satu produk budaya desa tersebut adalah Reyog Ki Onggo Pati. Reyog ini merupakan kesenian yang dijadikan ikon Desa Plunturan. Selain reyog, masih ada beberapa produk budaya, seperti Gajah-Gajahan; Jathilan; Ganongan; Tledekan; Karawitan; Wayang Kulit; Coke'an; Metik Desa; Metri Desa; Metri Tandur; Campursari; Sego Angkruk. Kesenian-kesenian tersebut dilaksanakan sebulan sekali setiap tanggal 25 pada event Selawenan (Wawancara dengan Kepala Desa Plunturan pada Tanggal 26 Agustus 2020). Potensi budaya yang dimiliki oleh Desa Plunturan dapat 
menarik perhatian para wisatawan lokal maupun asing. Hal ini menjadi kekuatan bagi seluruh aspek masyarakat harus memiliki kesadaran agar dapat turut serta dalam mengembangkan potensi budaya Reyog yang ada di Plunturan. Tidak sedikit masyarakat Plunturan kurang memahami konsep-konsep desa wisata. Berbicara mengenai konsep bagi masyarakat desa Plunturan itu sudah sangat jauh. Karena, seperti fakta dilapangan bahwa untuk keperluan administratif, aspek kelengkapan data serta kepengurusan saja di Desa Plunturan sendiri masih banyak kekurangan. Plunturan merupakan salah satu desa dengan peluang yang cukup besar untuk dapat terkenal dan bisa dikunjungi banyak wisatawan. Desa Plunturan sudah lebih dari cukup mengenai dana pelestarian budaya, karena selain bantuan pemerintah, Plunturan juga sudah bekerjasama dalam hal sponsorship dengan perusahaan swasta.

Permasalahan mitra adalah masyarakat Desa Plunturan masih belum memanfaatkan potensi seni yang dapat dikembangkan sebagai industri kreatif. Seni pertunjukan belum mampu menarik minat wisatawan untuk datang di desa plunturan. Selain itu kesadaran masyarakat memaksimalkan potensi yang dimilikinya masih sangat terbatas. Pemahaman terhadap konsep desa wisata belum terbangun, unsur-unsur sapta pesona (aman, tertib, sejuk, indah, ramah, dan kenangan) belum menjadi komitmen dan tanggung jawab bersama. Belum adanya pemandu wisata menjadikan potensi wisata belum terekspos dengan baik. Permasalahan yang harus diselesaikan oleh pemerintah Desa Plunturan, Kecamatan Pulung adalah sebagai berikut :

1. Mengidentifikasi pemangku kepentingan di tingkat desa yang akan terlibat dalam pengembangan produk wisata warisan budaya;

2. Mengidentifikasi kebijakan dan peraturan adat yang berkaitan dengan pengelolaan produk wisata warisan budaya;

3. Menginisiasi stakeholders yang akan mengelola produk wisata budaya.

Pengembangan wisata budaya desa Plunturan dapat diwujudkan dengan merumuskan strategi khusus untuk pencapaiannya. Selain strategi, dukungan masyarakat setempat adalah aspek utama. Pada dasarnya kekompakan/partisipasi seluruh masyarakat yang ada di Desa Plunturan sangat penting, karena tidak ada kelompok orang yang lebih paham mengenai desa Plunturan selain masyarakat Plunturan setempat. Berdasarkan hasil survei dan observasi pengabdi, adapun langkah yang dapat pengabdi pilih dalam rangka menjalankan serta mencapai tujuan yang dilakukan ialah dengan:

1. Pendampingan pembagian tanggung jawab pengembangan wisata budaya terhadap stakeholders yang terlibat; dan

2. Pendampingan penyusunan strategi terkait pengembangan wisata budaya Desa Plunturan

\section{METODE}

Adapun metode pengabdian yang dilaksanakan adalah sebagai berikut:

1. Survei Lapangan

Survei lapangan atau survei lokasi adalah tahapan awal yang sangat penting dalam merencanakan suatu kegiatan, dimana dalam surve lokasi tersebut, pengabdi dapat mengetahui suasana, keadaan masyarakat dan keadaan lingkungan Desa Plunturan sehingga perencanaan pengabdian dapat berjalan semaksimal mungkin sesuai yang diharapkan. Dalam kegiatan program pengabdian masyarakat khususnya metode survei dilakukan secara bersama (satu tim) untuk melihat jelas bagaimana kondisi dan situasi di Desa Pelunturan. 


\section{Analisis Situasi}

Merupakan tahap pengumpulan data yang ditempuh pengabdi sebelum merancang dan merencanakan program. Analisis situasi bertujuan untuk mengumpulkan informasi mencakup jenis dan bentuk kegiatan, pihak atau publik yang terlibat, tindakan dan strategi yang akan diambil, taktik, serta anggaran biaya yang diperlukan dalam melaksanakan program. Seperti dalam laporan sebagaimana hasil dari analisis situasi dijelaskan secara detail pihak-pihak yang terlibat dan berhasil kami wawancara mengenai program yang ada di Desa Plunturan. Sehingga dengan prosedur wawancara seperti ini kami dapat secara langsung akan menerima informasi dari pihak yang terpercaya.

3. Perancangan Kegiatan

Ialah suatu proses menentukan hal-hal yang ingin dicapai (tujuan) di masa depan serta menentukan berbagai tahapan yang diperlukan untuk mencapai tujuan tersebut. Dalam menentukan hal ini juga perlu melihat kondisi di desa tersebut. Seperti metode kegiatan sebelumnya, dengan memperdalam dan memperbanyak analisis situasi, maka perancangan kegiatan bisa dibuat dan dijalankan dengan strategi khusus dan pastinya tetap aspek utama partisipan masyrakat.

4. Pendampingan

Pendampingan ialah kegiatan dimana seseorang atau kelompok orang menjadi mentoring bagi masyarakat luas untuk mencapai tujuan yang telah direncanakan dan disepakati. Jadi, dalam pendampingan ini perlu untuk dibimbing dalam segala kegiatan yang dirincikan agar tidak terjadi kesalahan yang tidak diharapkan. Pendampingan yang dilakukan yaitu kepada lembaga Kelompok Sadar Wisata (Pokdarwis) dan Perangkat Desa yang terlibat dalam program pelestarian wisata budaya. Secara berkelanjutan, tujuan dari pendampingan ini adalah menyusun gagasan Desa Wisata Budaya Plunturan. Pendampingan ini tidak hanya dalam pembagian tanggung jawab pengembangan wisata budaya namun juga menyusun strategi yang dapat dilakukan dalam pengembangan wisata budaya.

5. Monitoring dan Evaluasi

Monitoring adalah kegiatan pemantauam untuk memperoleh informasi secara terusmenerus sehingga hasil sesuai dengan tujuan yang telah ditetapkan. Evaluasi yaitu kegiatan penilaian di akhir kegiatan untuk melihat pencapaian dari program yang dijalankan. Agar monitoring dan evaluasi ini dijalankan dengan stabil, dalam pelaksanaannya pengabdi membagi tugas sehingga kedua aspek ini dapat terkontrol secara baik. Pada setiap bulan secara berkala, kami melakukan monitoring, program dan kegiatan apa saja yang sudah dilaksanakan oleh Pokdarwis dan Perangkat Desa Plunturan.

6. Pelaporan

Pelaporan adalah aktivitas yang berlawanan arah dari pengawasan, Jika pengawasan dilakukan untuk mengetahui semua pelaksanaan kegiatan, maka pelaporan merupakan hasil dari seluruh kegiatan pelaksanaan sampai dengan pengawasan. 
Pelaporan merupakan akhir dari kegiatan sekaligus bukti kegiatan. Dalam laporan tentu yang ditulis sebagaimana yang terjadi di lapangan

\section{HASIL KARYA UTAMA DAN PEMBAHASAN}

Wisata berbasis budaya tidak dapat terlepas dari budaya lokal yang ada di suatu daerah. Budaya lokal adalah budaya yang dimiliki oleh masyarakat yang menempati lokalitas atau daerah tertentu yang berbeda dari budaya yang dimiliki oleh masyarakat yang berada di tempat lain (Theresia, dkk, 2015:57). Terkait dengan pembangunan, di dalam budaya lokal terdapat gagasan-gagasan (ideas, cultural system), perilaku-perilaku (activities, social system), dan artifak-artifak (artifacts, material culture) yang mengandung nilai-nilai yang berguna dan relevan bagi pembanunan masyarakat madani. (Theresia, dkk, 2015:59). Pentingnya budaya lokal dalam proses pembangunan juga dikemukakan oleh Colleta (1987), ada tiga alasan pokok mengenai pemanfaatan unsurunsur budaya lokal dalam melaksanakan pembangunan bagi masyarakat setempat. Pertama, unsur budaya lokal mempunyai legitimasi tradisional di mata masyarakat binaan yang menjadi sasaran program pemberdayaan dan pembangunan. Kedua, unsur-unsur budaya secara simbolis merupakan untuk komunikasi paling berharga dari penduduk setempat. Ketiga, unsur-unsur budaya mempunyai aneka ragam fungsi (baik yang terwujud maupun yang terpendam) yang sering menjadikannya sebagai sarana yang paling berguna untuk perubahan dibandingkan dengan yang tampak pada permukaan jika hanya dilihat dalam kaitan dengan fungsinya yang terwujud saja (Theresia, dkk, 2015:59$60)$.

Pengembangan wisata berbasis budaya lokal daerah telah dirancang di pemerintahan pusat, menjadi acuan dan arahan bagi pemerintah daerah, penggiat budaya dan para stakeholders kepariwisataan dalam pengembangan pariwisata budaya di tingkat provinsi, kabupaten/kota yang dapat dikembangkan dan dikemas sendiri menjadi produk wisata yang unik sesuai dengan karakter daerah masing-masing. Ada lima stakeholder yang harus terlibat dalam pengembangan wisata budaya yaitu pemerintah, komunitas, industri/bisnis, akademisi dan media (Model Pentahelix). Desa Plunturan merupakan salah satu desa yang terletak di Kabupaten Ponorogo memiliki banyak produk budaya dan masih dipertahankan. Setiap dusun yang ada di Desa Plunturan memiliki budaya atau kesenian yang berbeda-beda. Adapun para pelaku seni berasal dari lintas generasi. Regenerasi pelaku seni dilakukan melalui kelompok-kelompok seni. Para pelaku seni saat ini tidak menganggap potensi seni yang ada di Desa Plunturan sebagai mata pencaharian utama. Masyarakat memiliki mata pencaharian lain seperti petani, pedagang, pegawai negeri, aparat pemerintahan, guru, petugas kesehatan, karyawan swasta. Kondisi tersebut menyebabkan kurangnya inisiatif dari pelaku seni untuk menarik wisatawan dari luar wilayah. Mereka hanya akan menunggu ketika ada acara Selawenan dan undangan dari warga untuk menampilkan kesenian di acara-acara tertentu seperti perkawinan, acara bersih desa, khitanan, syukuran, penyambutan tamu, dan pentas sebagai delegasi budaya. Berdasarkan hal tersebut, pengabdi menganalisis beberapa masalah yang harus diselesaikan oleh Pemerintah Desa Plunturan, Kecaman Pulung yaitu :

a. Mengidentifikasi pemangku kepentingan di tingkat desa yang akan terlibat dalam pengembangan produk wisata warisan budaya;

b. Menginisiasi stakeholders yang akan mengelola produk wisata budaya.

Berdasarkan identifikasi atau analisis permasalahan yang telah dilakukan, pengabdi merancang kegiatan yang bertujuan untuk memecahkan permasalahan diatas yang terdiri dari kegiatan: 
a. Pendampingan pembagian tanggung jawab pengembangan wisata budaya terhadap stakeholders yang terlibat; dan

b. Pendampingan penyusunan strategi terkait pengembangan wisata budaya Desa Plunturan.

Kegiatan pendampingan pembagian tanggungjawab pengembangan wisata budaya terhadap stakeholders yang terlibat dan penyusunan strategi terkait pengembangan wisata budaya Desa Plunturan dilakukan pengabdi selama 6 bulan. Adpaun hasil dari kegiatan pendampingan pembagian tanggungjawab pengembangan wisata budaya terhadap stakeholders yang terlibat adalah sebagai berikut : Peran stakeholders dalam pengembangan wisata budaya Plunturan sangatlah penting, karena pembangunan desa wisata dan pelestariannya bergantuung pada kebijakan yang dirumuskan serta ditetapkan oleh para stakeholders. Maka dari itu perlu dilaksanakan pembagian tanggung jawab terhadap stakeholders yang terlibat. Pertama, perangkat Desa Plunturan berperan sebagai penyelenggara pengembangan wisata budaya dengan peraturan dan kebijakan yang berlaku. Salah satu kebijakan dalam perkembangan desa wisata budaya Plunturan adalah dengan mengadakan acara setiap sebulan sekali pada tanggal 25, acara itu disebut dengan Selawenan dan event setiap tahun pada tanggal 11 Januari. Adapun anggaran yang digunakan dalam acara tersebut berasal dari dana desa yang setiap tahunnya digelontorkan dana sebesar Rp 7.500.000,00. Peraturan mengenai menjadikan Desa Plunturan menjadi desa wisata telah tercantum di dalam dokumen Rencana Pembangunan Jangka Menengah Desa (RPJMDes) dan dokumen jangka panjang. Namun, untuk peraturan khusus terkait pelestarian dan pengembangan wisata budaya Plunturan masih belum direncanakan oleh stakeholders yang ada.

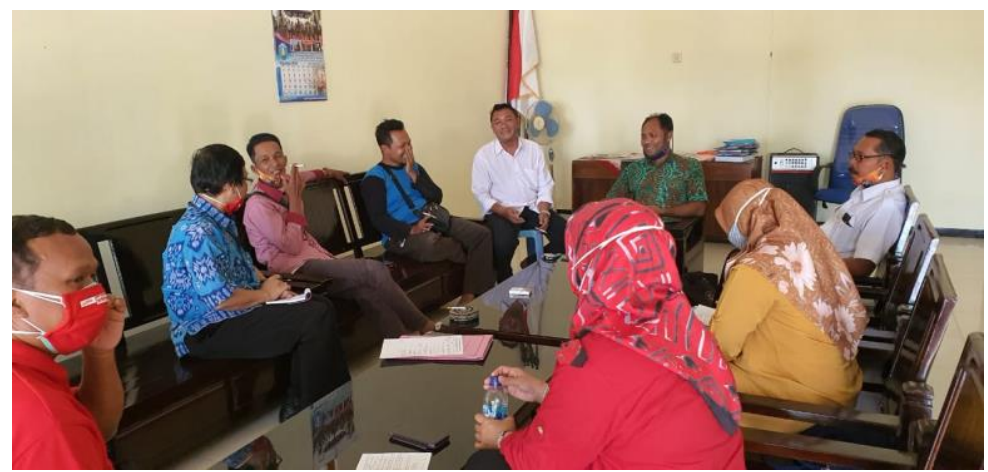

Gambar 1. Pendampingan penyusunan strategi pengembangan Wisata Budaya bersama stakeholders desa

Kedua, komunitas yang dimaksud adalah masyarakat setempat baik yang berbasis administrasi, geografi atau ikatan adat setempat sebagai komponen utama. Komunitas ini seperti Pokdarwis, Karang Taruna, BUMDes, PKK, dan lainnya. Dalam hal ini, Pokdarwis telah ikut serta dalam merancang rencana pembangunan desa yang berkaitan dengan menjadikan Plunturan sebagai desa wisata. Seperti mengusulkan pendirian sanggar dalam rencana pembangunan jangka menengah, pembuatan panggung untuk atraksi untuk menggelar kesenian dengan penonton berskala besar dalam rencana jangka panjang, dan peningkatan SDM masyarakat maupun pihak Pokdarwis dalam rencana pembangunan jangka pendek desa. Disamping kegiatan tersebut, Pokdarwis juga merupakan penggiat utama dalam hal memberikan dukungan kepada masyarakat untuk secara rutin melakukan pelatihan. Pokdarwis berencana membangun sebuah wadah atau 
destinasi. Konsep dari destinasi tersebut adalah pasar kawak selawenan yang bertempat di barat rumah salah satu warga desa. Area tersebut akan di konsep seperti pasar dengan nuansa dan gaya atau tradisi tempo dulu. Masyarakat disana pun dapat berjualan sesuai dengan aturan yang sudah ditetapkan, seperti dari pakaiannya, bagaimana cara penyajian atau penjualan, bagaimana konsep makanan yang dijual, dan lain sebagainya. Untuk pelatihan internal, Pokdarwis melakukan studi banding dengan Punden Sari di Kecamatan Nglames Madiun agar mendapatkan informasi tentang kegiatan atau program apa yang dilaksanakan di Punden Sari guna diterapkan sesuai dengan kondisi dan kearifan lokal yang ada di Plunturan. Disamping itu pokdarwis juga menjadikan kelompok di Punden Sari sebagai mitra. Sebagai bentuk promosi, Pokdarwis juga telah melakukan penyebaran pamflet serta melakukan sosialisasi guna membangkitkan kesadaran dan kepedulian masyarakat untuk mengembangkan desa wisata budaya Plunturan. Namun, pihak Pokdarwis belum melakukan monitoring terhadap kegiatan yang berkaitan dengan pengembangan wisata budaya Desa Plunturan.

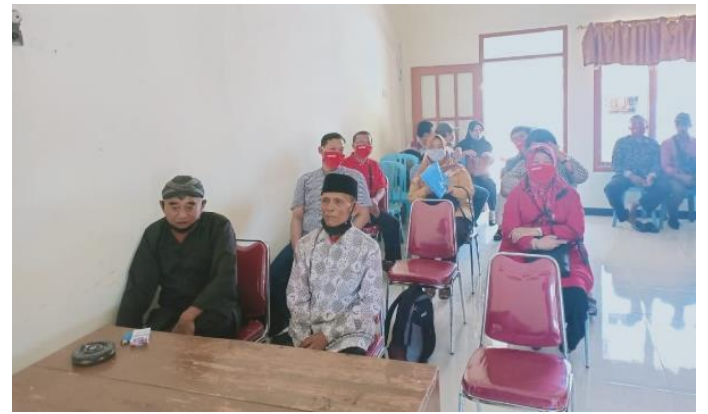

Gambar 2. Koordinasi dengan komunitas di Desa Plunturan terkait pengelolaan budaya dan promosi

Ketiga, industri/bisnis yang dimaksud adalah para pelaku usaha yang mendukung pengembangan wisata berbasis budaya secara berkelanjutan dan bertanggung jawab. Seperti bentuk kerjasama Desa Plunturan dengan PT Djarum 76 dalam salah satu penyelenggaraan event kesenian yaitu Selawenan dan kegiatan Pasar Hepiii yang dilaksanakan di Taman Sor Sengon.

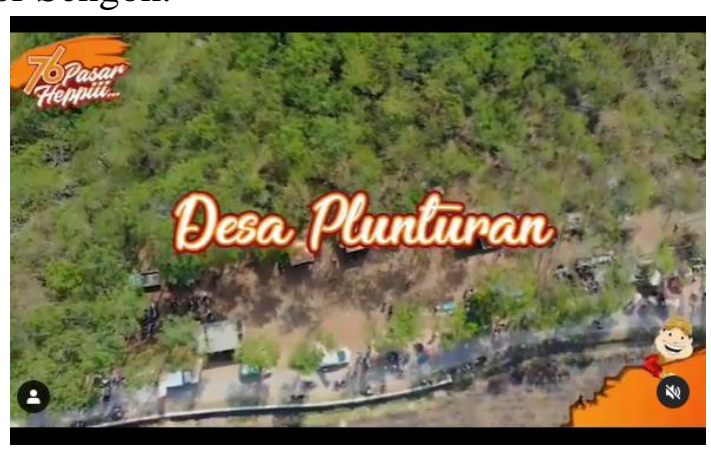

Gambar 3. Pembuatan video promosi yang bekerjasama dengan sektor bisnis Sumber: instagram @desa_plunturan

Keempat, Akademisi sebagai pengembang sektor pariwisata melalui penelitian dan pengabdian. Contohnya seperti pengabdian yang kami dilakukan dalam mengembangkan desa wisata budaya Plunturan dengan pembekalan Bahasa, 
pendampingan pembagian tanggung jawab pengembangan wisata budaya terhadap stakeholders, pendampingan penyusunan strategi terkait pengembangan wisata budaya Desa Plunturan, pendampingan meningkatkan kesadaran masyarakat melalui program aksi pengembangan wisata budaya, dan lain-lain.

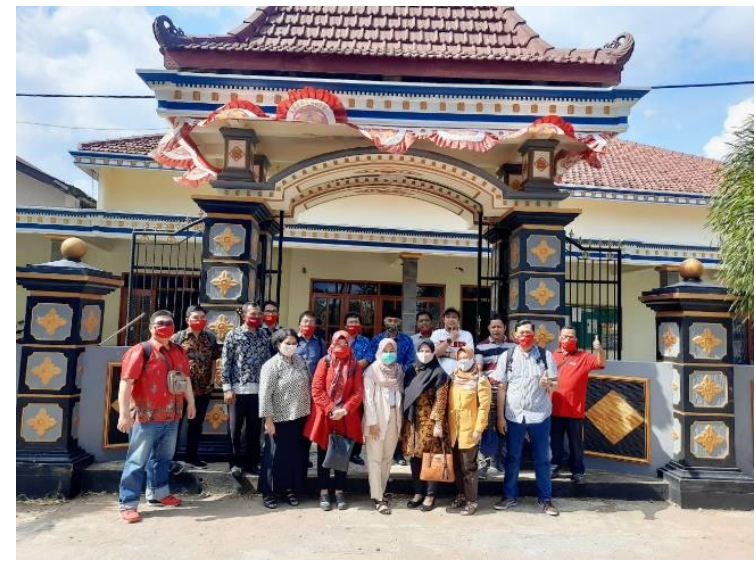

Gambar 4. Pengabdian bersama antar prodi dan fakultas untuk pembekalan bahasa asing dan pengembangan wisata budaya

Sedangkan media sebagai penyalur informasi yang mempunyai fokus pada tematema wisata berbasis budaya baik berupa industri atau media arus utama (mainstream media) dan juga media alternatif (alternative media) yang berbasis komunitas atau jejaring sosial. Selain berguna sebagai penyalur informasi, media juga dapat dijadikan wadah mempromosikan Desa Wisata Plunturan, karena media memiliki jangkauan yang luas, sehingga masyarakat di daerah lain baik dalam maupun luar negeri dapat tertarik untuk berkunjung ke desa wisata budaya Plunturan.
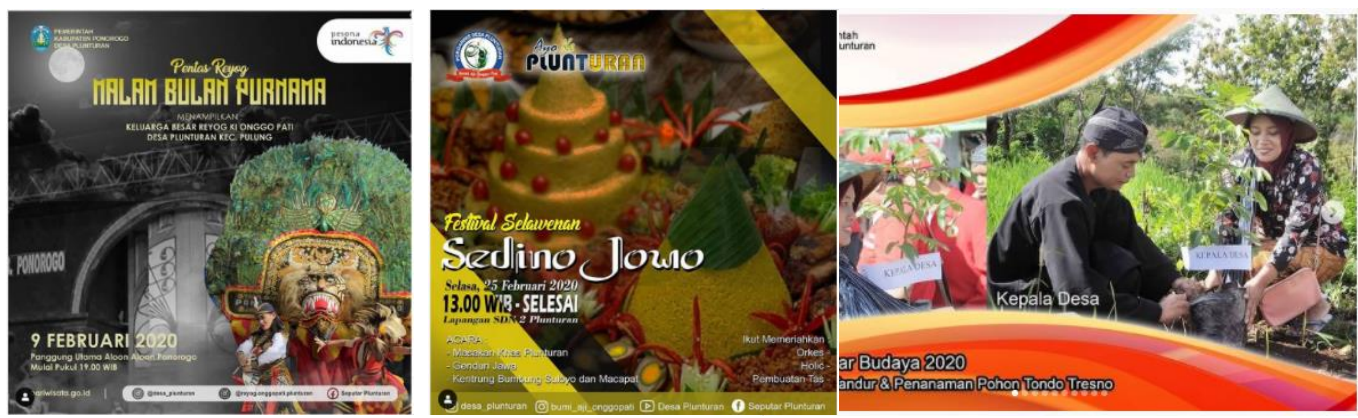

Gambar 5. Pemanfaatan media sosial instagram oleh karang taruna sebagai media informasi dan promosi Sumber: instagram @desa_plunturan

Kegiatan pendampingan penyusunan strategi yang pertama kali dilakukan adalah menganalisis kekuatan (strength), kelemahan (weakness), peluang (opportunity), dan ancaman (threat) (sering disebut analisis SWOT) yang terdapat dalam desa Plunturan. Analisis tersebut dilakukan sebelum menerapkan sebuah kebijakan dan menyusun sebuah strategi. Tujuan dari analisis SWOT ini adalah agar para stakeholder mengetahui kekuatan (strength), kelemahan (weakness), peluang (opportunity), dan ancaman (threat) yang terdapat dalam desa Plunturan supaya semua keputusan yang diambil oleh para stakeholders dapat tepat sasaran. Adapun kekuatan (strength) yang dimiliki Desa Plunturan untuk mengembangkan desa wisata Plunturan adalah sebagai berikut: 
1. Desa Plunturan memiliki beberapa dusun, dan setiap dusun memiliki kesenian yang berbeda-beda, sehingga Desa Plunturan memiliki produk budaya yang beragam, seperti Reog, Gajah-Gajahan; Jathilan; Ganongan; Tledekan; Karawitan; Wayang Kulit; Coke'an; Metik Desa; Metri Desa; Metri Tandur; Campursari; Sego Angkruk.

2. Reyog yang dimiliki oleh desa tersebut merupakan reyog istimewa, karena dalam tariannya tidak ada tambahan gerakan (masih bersifat original) sehingga berbeda dengan reog di daerah lain. Reog ini disebut dengan nama reog Ki Onggo Pati.

3. Kegiatan pelatihan reog dan produk kesenian yang lainnya dilakukan secara rutin.

4. Desa Plunturan juga memiliki reog lintas generasi yang terdiri dari reog sepuh, reog perempuan, reog remaja, dan reog anak. Dengan adanya reog lintas generasi ini, kesenian reog yang menjadi ikon Desa Plunturan tidak akan mudah punah.

5. Cara lain dalam melestarikan dan mengembangkan budaya Plunturan adalah menggelar event dalam setiap bulan pada tanggal 25 yang disebut dengan "Selawenan" dan event setiap tahun pada tanggal 11 Januari.

6. Adapun anggaran yang digunakan dalam event tersebut berasal dari dana desa yang setiap tahunnya digelontorkan dana sebesar Rp 7.500.000.

7. Adanya Kapispam (Kelompok Pengelola Sanitasi dan Air Minum). Selain menyediakan air bersih untuk masyarakat desa, pengelolaan kapispam juga membantu meningkatkan jumlah kas desa. Dengan begitu, kegiatan pengembangan desa wisata budaya Plunturan tidak akan memiliki hambatan dalam hal anggaran.

8. Desa Plunturan memiliki banyak komunitas, seperti pokdarwis, karang taruna, dll yang dapat menjadi penggiat utama dalam kegiatan pengembangan desa wisata Plunturan. Masyarakat desa Plunturan juga pernah melakukan fotografi dan videografi agar dapat mengambil footage secara baik, sehingga foto dan video yang diunggah di website/media sosial dapat menarik pengunjung.

Hasil analisis SWOT, dapat membantu Pemerintah Desa Plunturan dalam mengembangkan perencanaan wisata budaya. Dampak pengembangan wisata budaya sangat beragam ke sektor-sektor lainnya. Ibarat wisata budaya sebagai motor penggerak, sektor lainnya seperti UMKM, pengolahan makanan dan minuman, jasa, dan lain-lain dapat mengikuti. Pengembangan produk unggulan lokal yang selama ini belum dikelola dengan baik dapat dikembangkan, misalnya singkong, jagung, dan ubi jalar. Di bidang kuliner juga demikina, diharapkan dapat menyediakan makanan dan minuman khas Plunturan yang membuat wisatawan tertarik. Selain itu, penyusunan calendar of event perlu dilakukan dan dipublikasikan melalui website dan media sosial Desa Plunturan atau Pokdarwis. Hal ini memudahkan wisatawan luar daerah menentukan jadwal berkunjung ketika ada event. Agar wisatawan nyaman dan terfasilitasi dengan baik, Pokdarwis dapat membuat paket wisata budaya dan kuliner serta perancangan aktifitas bersama masyarakat (living with local community). Sehingga wisatawan dapat terjun langsung merasakan kegiatan sehari-hari masyarakat desa.

Untuk mendukung melaksanakan aktifitas ini, maka masyarakat Desa Plunturan memerlukan pelatihan keterampilan memandu (guiding) dan berbahasa asing untuk memberikan pelayanan kepada wisatawan mancanegara. Selain itu, Pokdarwis atau BUMDes (Badan Usaha Milik Desa) dapat menciptakan brand atau merk pada produk lokal, misalnya pada kerajinan, makanan khas, oleh-oleh khas Plunturan. Kearifan lokal masyarakat adat Desa Plunturan masih kental dengan budaya Reyog dan awig-awig (aturan adat setempat) nya. Pemerintah desa beserta stakeholders terkait mengajak masyarakat untuk bergotong royong bersama dalam meningkatkan dan mengembangkan wisata budaya. Meningkatkan kesadaran masyarakat dapat dilakukan melalui program 
ekonomi kreatif yang memanfaatkan potensi Desa Plunturan. Seseorang ingin melakukan perjalanan wisata dipengaruhi oleh faktor pendorong dan faktor penarik yang memotivasi wisatawan untuk melakukan perjalanan wisata. Sebagai faktor penarik wisata, Desa Plunturan harus melakukan promosi baik secara offline maupun online. Karang taruna sebagai agen penggerak pemuda yang dapat membuat video profil desa untuk menarik wisatawan.

Setelah strategi pengembangan Desa Wisata Budaya Plunturan terbentuk, pengabdi melakukan monitoring dan evaluasi kegiatan atau program setiap bulan secara berkala. Berdasarkan kegiatan dan evaluasi monitoring yang didapatkan, pihak pemerintah Desa Plunturan, Pokdarwis dan BUMDes masih belum dapat melaksanakan kegiatan administratif umum serta keuangan secara tertib dengan menggunakan komputer. Di samping itu, kegiatan menjadikan Desa Plunturan tempat wisata dan edukasi Kesenian Reog, pendaftaran Tarian Reog Plunturan menjadi Hak Cipta/ HKI Tarian asli Desa Plunturan dan nomor induk kesenian bagi kelompok-kelompok Kesenian Desa Plunturan, serta perluasan marketplaces produk unggulan desa belum berjalan. Selain itu, kegiatan pelatihan Bahasa asing yang digunakan sebagai Guide Tour di Desa Plunturan tidak dapat berjalan efektif karena terhambat oleh tingkat partisipasi masyarakat Desa Plunturan yang sangat minim dalam kegiatan pelatihan. Di sisi lain, kegitan pengelolaan social media (termasuk website dan Instagram) sebagai wadah promosi telah berjalan dengan baik. Adapun Media social tersebut dikelola oleh Karang Taruna Desa Plunturan. Kegiatan sosialisasi oleh BUMDES dan Pokdarwis kepada masyarakat akan program menunjang pembangunan Desa Wisata Budaya Plunturan juga berjalan dengan lancar. Pembuatan desain/blue print lokasi pusat UMKM (strategis dan dekat dengan sanggar budaya) oleh Pemerintah Desa dan Pokdarwis telah terlaksana. Adapun kegiatan pembangunan fasilitas, pelaksanaan pagelaran acara kesenian dan program berkelanjutan lainnya telah tercantum dalam dokumen rancangan pembangunan jangka menengah desa (RPJMDes) dan perencanaan jangka panjang.

\section{KESIMPULAN}

Secara umum pengembangan desa wisata budaya Plunturan sangat bergantung pada peran para stakeholders (pemerintah/perangkat desa, komunitas, industri, akademisi, serta media) dan bagaimana mereka mengidentifikasi suatu kekuatan, kelemahan, peluang, serta ancaman untuk ditransformasikan menjadi sebuah strategi agar penerapan kebijakan dapat tepat sasaran. Untuk itu, pengabdi mengusulkan kegiatan Pendampingan pembagian tanggung jawab pengembangan wisata budaya terhadap stakeholders yang terlibat; dan Pendampingan penyusunan strategi terkait pengembangan wisata budaya Desa Plunturan. Kegiatan diawali dengan survei lapangan guna mengetahui kondisi dan situasi di Desa Pelunturan. Selanjutnya, dilakukan analisis dan identifikasi permasalahan yang ada terdapat di Desa Plunturan. Setelah didapatkan permasalahan, pengabdi menyusun perancangan kegiatan pemdampingan dan dilanjut kegiatan pendampingan. Dengan adanya kegiatan pendampingan ini, para stakeholders yang terlibat dalam pengembangan desa wisata budaya Plunturan dapat mengetahui dan bertanggung jawab terhadap perannya masing masing serta dapat menganalisis faktor-faktor internal maupun 
eksternal (kekuatan, kelemahan, peluang, dan ancaman) yang terdapat di Desa Plunturan, sehingga dapat diubah menjadi sebuah strategi pengembangan desa wisata budaya Plunturan untuk kedepannya. Terakhir, pengabdi melakukan monitoring dan evaluasi terkait jalannya strategi pengembangan Desa Wisaya Budaya Plunturan. Kegiatan monitoring dan evaluasi dilakukan agar para stakeholders mengetahui perkembangan dan apa saja yang perlu diperbaiki dalam pelaksanaan strategi pengemgembangan Desa Wisata Budaya Plunturan.

\section{DAFTAR PUSTAKA}

Hartono, Agus \& Sumaryadi. 2018. Pedoman Pengembangan Wisata Tematik Berbasis Budaya. Jakarta: Kementerian Pariwisata

Ooi, Chan-Seng. 2006. Tourism and the Creative Economy in Singapore

Peraturan Menteri Pariwisata Republik Indonesia Nomor 3 Tahun 2018 tentang Petunjuk Operasional Pengelolaan Dana Alokasi Khusus Fisik Bidang Pariwisata. Kementerian Pariwisata: 2018

Purnomo, Rochmat Aldy. 2016. Ekonomi Kreatif, Pilar Pembangunan Indonesia. Surakarta: Ziyad Visi Media

Rahim, Firmansyah. 2012. Pedoman Kelompok Sadar Wisata. Jakarta: Kementerian Pariwisata dan Ekonomi Kreatif

Theresia, Aprillia Krisnha dkk, 2015. Pembangunan Berbasis Masyarakat. Bandung. Alfabeta

Yoeti, Oka A. 1985. Pengantar Ilmu Pariwisata. Bandung: Angkasa 